\title{
Voltammetric behaviour of mitoxantrone at a DNA-biosensor
}

\author{
A.M. Oliveira Brett ${ }^{\text {a, }}{ }^{*}$, T.R.A. Macedo ${ }^{\text {b }}$, D. Raimundo ${ }^{\text {b }}$, M.H. Marques ${ }^{\text {b }}$, \\ S.H.P. Serrano ${ }^{c}$ \\ a Departamento de Química, Faculdade de Ciências e Tecnologia, Universidade de Coimbra, 3000 Coimbra, Portugal \\ ${ }^{\mathrm{b}}$ Faculdade de Medicina, Universidade de Coimbra, 3000 Coimbra, Portugal \\ ' Instituto de Química, Universidade de São Paulo, C.P. 26077, 05599-970 São Paulo, Brazil
}

Received 17 February 1998; accepted 14 April 1998

\begin{abstract}
The surface of an electrochemical glassy carbon electrode was modified with a layer of double-stranded DNA (dsDNA) or with double-stranded DNA conditioned in single-stranded DNA (ssDNA) and was used to investigate mitoxantrone-DNA interactions. Differential pulse and square wave voltammetry were applied to develop an electroanalytical procedure for the determination of mitoxantrone and evaluate its interaction with dsDNA or ssDNA immobilized on the electrode surface. The results demonstrate that MTX interaction with DNA is not specific to either guanine or adenine bases. The kinetics of the mitoxantrone-DNA interaction is slow and damage to DNA was followed with time. (C) 1998 Elsevier Science S.A. All rights reserved.
\end{abstract}

Keywords: Bioelectrochemistry; DNA interaction; Mitoxantrone; DNA-biosensor; Voltammetry

\section{Introduction}

Mitoxantrone (1,4-dihydroxy-5,8-bis[[2-[(2-hydroxyethyl)amino]ethyl]amino]-9,10-anthracenedione) is an anthraquinone, structurally related to doxorubicin, an anthracycline antibiotic. It has a planar heterocyclic ring structure, the basic side groups critical for intercalation into DNA and the quinone prosthetic group, which together could confer chemical reactivity<smiles>CNCCNc1ccc(NCCNCCN)c2c1C(=O)c1c(O)ccc(O)c1C2=O</smiles>

The positively charged, nitrogen-containing side chains project out from the molecule, and stabilize the ring in between base pairs by intercalating with the nega-

* Corresponding author. Tel.: + 351-39-835295; Fax: + 351-39835295; E-mail: brett@cygnus.ci.uc.pt tively charged phosphate backbone of DNA. Originally synthesized as stable dyes (Zee-Cheng and Cheng, 1978; Murdock et al., 1979; Smith, 1983), the anthracenediones are used as antitumour antibiotics (Riggs, 1992) for leukemia and breast cancer treatment, due to their interaction with DNA. Mitoxantrone has been shown to induce condensation of nucleic acids but the most dominant molecular mechanism of antitumour action appears to be the induction of long-term DNA damage. Alkaline elution assays of DNA integrity indicate both single and dsDNA breaks mediated by topoisomerase II (Bowden et al., 1985). However, the precise nature of the interactions and lesions produced is not clear. The cytotoxic effects caused by the lack of selectivity, although less than from other anticancer drugs, cause mielosuppression, cardiac toxicity and mucositis as well as other common effects.

DNA is a structurally polymorphic macromolecule which, depending on nucleotide sequence and environmental conditions, can adopt a variety of conformations. The double helical structure of DNA consists of two strands, each of them on the outside of the double helice and formed by alternating phosphate and pentose groups in which the phosphodiester bridges provide the covalent continuity. The two chains of the double helix are held together by hydrogen bonds between purines and pyrim- 
idine bases. The first DNA structure proposed by Watson and Crick is known as the B-form and is characterized to be right-handed with 10 nucleotides per turn and is stabilized by bound water that fits perfectly into the minor groove. Later it was discovered that when DNA is strongly dehydrated a structural alteration occurs due to a greater electrostatic interaction between the phosphate groups and this form was designated by A-DNA. It is also right-handed, has 11 nucleotides per turn and the pentoses of the nucleotides are in a conformation which causes an increase in the double helix diameter and a decrease in its length. In solution it is the general view that at least part of the mitoxantrone molecule is accommodated in the minor groove of B-DNA (Lown et al., 1985).

The different structural forms of the double helix lead to different dynamic interactions, and the geometry of the grooves is important in allowing or preventing access to bases. Topoisomerase enzymes catalyse breaking and rejoining, knotting and unknotting and concatenation/deconcatenation of DNA via covalently linked enzyme-DNA intermediate, the so-called cleavable complex (Wang, 1991). This cleavable complex is involved in a reaction which alters the topology of DNA by introducing a temporary double-strand break in the sequence through which an intact helix can pass. Some research work showed evidence that mitoxantrone is a topoisomerase II poison (Murdock et al., 1979; Capranico and Zunino, 1992) that stabilizes the cleavage complex and prevents the linking of DNA strands (Fox and Smith, 1990).

The electrochemical DNA-biosensor enables us to evaluate and predict DNA interactions and damage by health hazardous compounds based on their binding to nucleic acids. In this work several situations were studied using a bare glassy carbon electrode in a solution containing dsDNA and mitoxantrone, and using a glassy carbon electrode covered by dsDNA or dsDNA modified in ssDNA solution, forming the DNA-biosensor, and immersed in a solution containing mitoxantrone.

\section{Experimental}

Mitoxantrone (MTX) (dihydroxyanthracenedione) was a synthetic sample solution of Novantrone ${ }^{\circledR}$ (mitoxantrone hydrochlorate) that was supplied by Lederle Laboratories, Gosport, UK. The MTX sample of $2 \mathrm{mg} \mathrm{ml}^{-1}\left(4.5 \times 10^{-3} \mathrm{M}\right)$ was kept away from light to avoid photodecomposition and at a temperature of $\sim 3^{\circ} \mathrm{C}$. Solutions were always prepared just before the experiments

Calf thymus DNA (sodium salt, type I), was obtained from Sigma and was used without further purification. Acetate buffer solutions of ionic strength 0.2 at $\mathrm{pH} 4.5$ were used in all experiments, and were prepared using analytical grade reagents and purified water from a Millipore Milli-Q system. All experiments were done at room temperature.

Single stranded DNA (ssDNA) was prepared by treating an accurately weighed sample of approximately $3 \mathrm{mg}$ of DNA with $0.5 \mathrm{ml}$ of $60 \%$ pure perchloric acid; after dissolution, $0.5 \mathrm{ml}$ of $9 \mathrm{M} \mathrm{NaOH}$ was then added to neutralize the solution followed by $49 \mathrm{ml}$ of $\mathrm{pH} 4.5$ acetate buffer.

The DNA-biosensor was prepared by covering a glassy carbon electrode (Tokai, GC20, $3 \mathrm{~mm}$ diameter) with $3 \mathrm{mg}$ of dsDNA dissolved in $80 \mu \mathrm{l}$ of $\mathrm{pH} 4.5$ acetate buffer and leaving the electrode to dry. After drying, the electrode was immersed in acetate buffer solution and a constant potential of $+1.4 \mathrm{~V}$ applied during $5 \mathrm{~min}$. It was then transferred to a solution containing singlestranded DNA and differential pulse voltammograms were recorded in the range 0.0 to $+1.4 \mathrm{~V}$ until stabilization of the peak currents that correspond to adenine and guanine electro-oxidation occurred.

Voltammograms were recorded using a $\mu$ Autolab potentiostat/galvanostat running with GPES version 3 software, from Eco-Chemie, Utrecht, Netherlands. The working electrode was either a glassy carbon disc electrode $1 \mathrm{~mm}$ diameter, Cypress Systems, Lawrence, USA, together with $\mathrm{Ag} / \mathrm{AgCl}(3.0 \mathrm{M} \mathrm{KCl})$ reference electrode, or a glassy carbon disc electrode $3 \mathrm{~mm}$ diameter, Tokai, GC20, with saturated calomel electrode (SCE) as reference electrode; the counter electrode was always a $\mathrm{Pt}$ wire. All electrodes were contained in a one-compartment cell. Differential pulse voltammetry conditions were: pulse amplitude $50 \mathrm{mV}$, pulse width $70 \mathrm{~ms}$ and scan rate $5 \mathrm{mV} \mathrm{s}^{-1}$. Square wave voltammetry conditions were: frequency $50 \mathrm{~Hz}$, pulse amplitude $50 \mathrm{mV}$ and scan increment $2 \mathrm{mV}$, corresponding to an effective scan rate of $100 \mathrm{mV} \mathrm{s}^{-1}$.

\section{Results and discussion}

Voltammograms obtained with DNA double-stranded (dsDNA) and single-stranded (ssDNA) show the greater difficulty for the transfer of electrons from the inside of the double-stranded rigid form of DNA to the electrode surface than from the flexible single-stranded form where the bases are in close proximity to the electrode surface (reviewed by Oliveira Brett and Serrano, 1997). The roughness of a solid electrode surface means that double helix DNA has some difficulty in following the surface contours whereas single-stranded unwound DNA molecules can approach closer to the electrode surface, because of their greater flexibility.

The electrochemical oxidation of nucleic acids at $\mathrm{pH} 4.5$ is due to the oxidation of the purine residues (Brett et al., 1994), guanine and adenine, in the polynucleotide chains. The oxidation of the pyrimidine residues 
(Oliveira Brett and Matysik, 1997) only occurs for a high $\mathrm{pH}$ value of 10.0 and very positive potentials.

\subsection{Electrochemistry of DNA and MTX in solution}

The oxidation of pure MTX at a glassy carbon electrode using square wave voltammetry originates three current peaks Fig. 1(b), and the addition of dsDNA or ssDNA caused modifications to this oxidation behaviour. The alterations in electrode response that occurred in an aqueous solution containing $3 \mathrm{mg} \mathrm{ml}^{-1}$ of doublestranded or $60 \mu \mathrm{g} \mathrm{ml}^{-1}$ of ssDNA and $6.38 \times 10^{-5} \mathrm{M}$ of MTX in $0.1 \mathrm{M}$ acetate buffer $\mathrm{pH} 4.5$ were investigated.

\subsection{1. dsDNA and MTX in solution}

MTX is interacting possibly by intercalation with the dsDNA in solution; its oxidation follows a different pathway than when no dsDNA is present in the solution [Fig. 1(b)]. In the presence of dsDNA only two small peaks $\left(E_{\mathrm{p} 1}=+0.48 \mathrm{~V}\right.$ and $\left.E_{\mathrm{p} 2}=+0.66 \mathrm{~V}\right)$ appeared, because the MTX groups involved in bonding with DNA are not available for oxidation. The peaks corresponding to the oxidation of the DNA bases at a glassy carbon electrode at $\mathrm{pH} 4.5$, for the guanine group at a potential of $+0.84 \mathrm{~V}$ and for the adenine group at a potential of $+1.16 \mathrm{~V}$ (Brett et al., 1994), were not detectable. This means that no immediate significant change was caused to the double helical DNA structure and damage to dsDNA is a function of time. Other methods, such as scanning electron microscopy (Lown et al., 1984), have

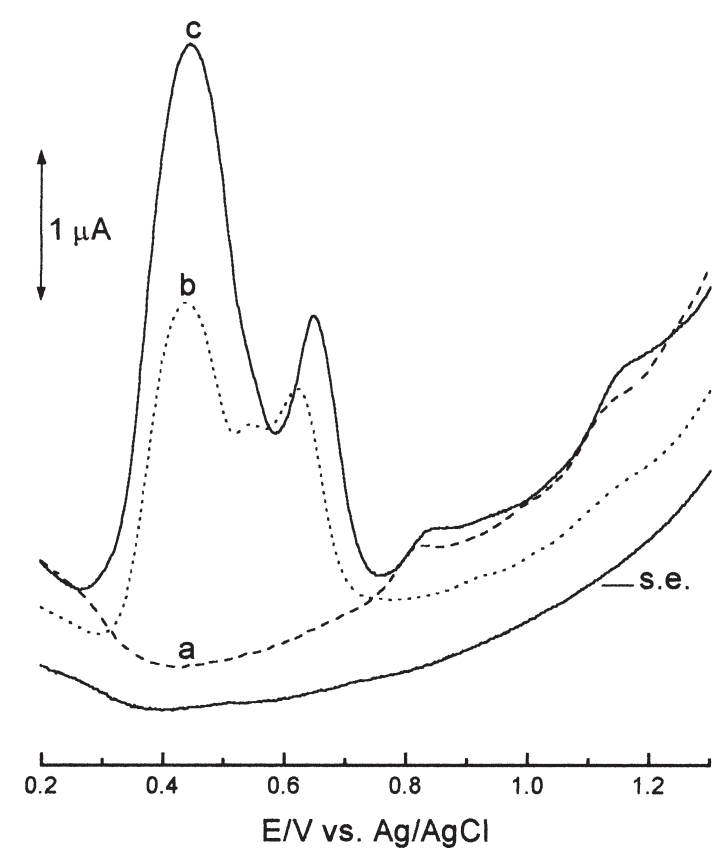

Fig. 1. Square wave voltammograms of (a) $60 \mu \mathrm{g} \mathrm{ml}^{-1}$ of ssDNA (-- ); (b) $6.38 \times 10^{-5} \mathrm{M}$ of MTX $(\cdots)$; (c) mixture of $60 \mu \mathrm{g} \mathrm{ml}^{-1}$ of ssDNA with $6.38 \times 10^{-5} \mathrm{M}$ of MTX (- $(-$ Supporting electrolyte (s.e.) $0.1 \mathrm{M}$ acetate buffer $\mathrm{pH} 4.5$. Frequency $50 \mathrm{~Hz}$. Glassy carbon disc electrode (1 $\mathrm{mm}$ diameter). given evidence of the intercalation bonding between MTX and dsDNA and extensive formation of networks of linked DNA molecules, through the MTX amino group that electrostatically bonds to the DNA phosphate groups. However, when the solution of dsDNA was added to the MTX solution, the interaction of MTX with dsDNA in solution immediately caused the appearance of a dark blue colour precipitate with the appearance of a ball of wool, which must result from the intercalation and condensation process, via electrostatic crosslinking (Dunn and Goa, 1996), and compacting of the double helix. The ability to condense nucleic acids is believed to be responsible for the cytotoxic activity of MTX (Kapuscinski and Darzynkiewicz, 1985, 1986). As expected, after the formation of this dark blue ragged precipitate no peaks were observed in the voltammograms and only with strong stirring of the solution to maximize mass transport to the electrode surface was it possible to obtain a small electrochemical signal.

\subsection{2. ssDNA and MTX in solution}

In other experiments ssDNA was added to the MTX solution. The peaks corresponding to the oxidation of the bases guanine and adenine in ssDNA were not significantly affected by the presence of MTX, [Fig. 1(a) and Fig. 1(c)], and as also occurred in the presence of dsDNA only two peaks were observed for MTX oxidation. Nevertheless these peaks were ten times bigger than for mitoxatrone alone and probably some adsorption of the MTX-ssDNA complex on the electrode surface occurred.

\subsection{Glassy carbon electrode surface-modified with dsDNA and MTX}

The glassy carbon electrode, $1 \mathrm{~mm}$ diameter, was modified through immobilization by adsorption on its surface of, twice (due to small electrode diameter) $6 \mu \mathrm{l}$ of a solution containing $3 \mathrm{mg} \mathrm{m}^{-1}$ dsDNA. After the electrode was dried, $3 \mu \mathrm{l}$ of a solution containing $4.5 \times$ $10^{-3} \mathrm{M}$ of MTX were placed on its surface and the electrode allowed to dry at room temperature for $48 \mathrm{~h}$. Due to strong dehydration a structural alteration will form ADNA and a greater electrostatic response between the phosphate groups and MTX will occur during the drying time. After this period the electrode was immersed in the $\mathrm{pH} 4.5$ acetate buffer supporting electrolyte solution and a very large peak was observed at a potential corresponding to the oxidation of guanine $\left(E_{\mathrm{p}}=+0.84 \mathrm{~V}\right)$ (Fig. 2), whereas practically no peak was observed at a potential corresponding to the oxidation of adenine $\left(E_{\mathrm{p}}\right.$ $=+1.16 \mathrm{~V})$. In Fig. $1(\mathrm{~b})$ is a square wave voltammogram of MTX in buffer for comparison. On repeating the experiment after $72 \mathrm{~h}$, the peak at $+0.8 \mathrm{~V}$ has practically disappeared. This can be understood by considering that, under the experimental conditions described, a preferen- 


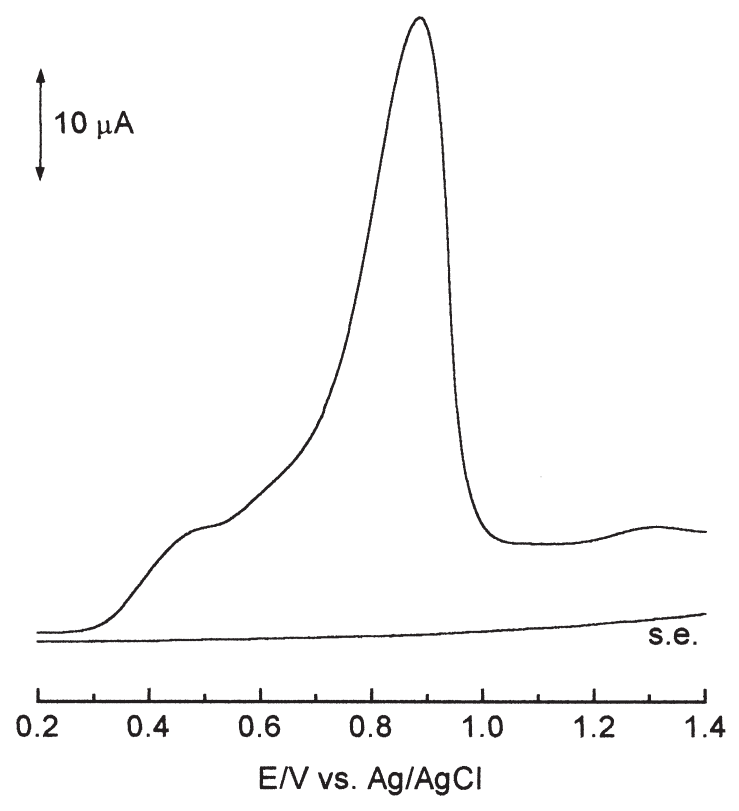

Fig. 2. Square wave voltammogram of a glassy carbon disc electrode ( $1 \mathrm{~mm}$ diameter) containing $3 \mathrm{mg} \mathrm{ml}^{-1} \mathrm{dsDNA}$ and $3 \mu \mathrm{l}$ of a solution containing $4.5 \times 10^{-3} \mathrm{M}$ of MTX on its surface, after being dryed for $48 \mathrm{~h}$. Supporting electrolyte (s.e.) $0.1 \mathrm{M}$ acetate buffer $\mathrm{pH} 4.5$. Frequency $50 \mathrm{~Hz}$.

tial intercalation near guanine bases occurs, freeing them and giving rise to the big guanine oxidation peak current in the first experiment after $48 \mathrm{~h}$. As no more MTX was added to the electrode surface and it is considered that all the MTX had reacted with the dsDNA after $48 \mathrm{~h}$, no more guanine base can be liberated and oxidized which could lead to the disappearance of the guanine peak after $72 \mathrm{~h}$. Spectroscopic studies have shown that MTX interacts preferentially with DNA binding with guanine, cytosine base pairs (Kapuscinski et al., 1981; Foye et al., 1982; Lown et al., 1985).

\subsection{Glassy carbon electrode surface-modified with dsDNA}

The glassy carbon electrode ( $3 \mathrm{~mm}$ diameter) was modified by the immobilization by adsorption on its surface of $30 \mu \mathrm{ldsDNA} 3 \mathrm{mg} \mathrm{ml}^{-1}$, and allowing the electrode to dry at room temperature. The electrode was electrochemically conditioned by application of a square wave potential scan between 0 and $+1.4 \mathrm{~V}$ in the buffer solution. The electrochemical pretreatment of the dsDNA-modified glassy carbon electrode was essential to obtain reproducible results. Afterwards the electrode was placed in a buffer solution containing $4.46 \times 10^{-5} \mathrm{M}$ of MTX at $+1.4 \mathrm{~V}$ deposition potential during $120 \mathrm{~s}$ and no peaks were observed. The electrode was removed from the solution and allowed to dry at room temperature for different time periods (Fig. 3), after which it was again immersed in the same solution and the experiment repeated. Comparing the results observed with Fig. 1(b)

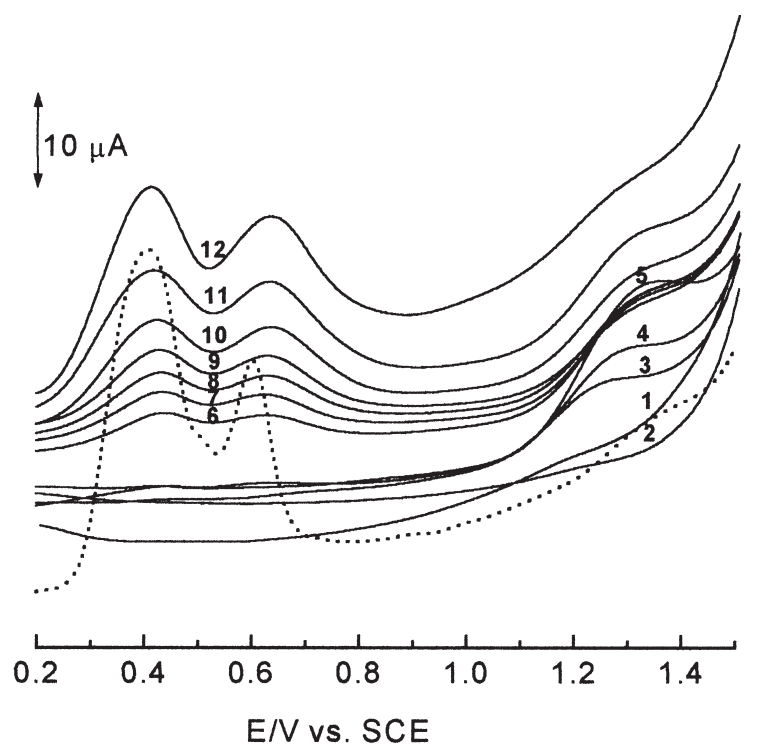

Fig. 3. Square wave voltammograms at a glassy carbon disc electrode ( $3 \mathrm{~mm}$ diameter) modified by the immobilization by adsorption on its surface of $30 \mu \mathrm{ldsDNA} 3 \mathrm{mg} \mathrm{m}^{-1}$, and allowing the electrode to dry at room temperature. Variation with time: (1) $0 \mathrm{~h}$; (2) $1 \mathrm{~h}$; (3) $2 \mathrm{~h}$; (4) $8 \mathrm{~h}$; (5) $17 \mathrm{~h}$; (6) $21 \mathrm{~h}$; (7) $24 \mathrm{~h}$; (8) $28 \mathrm{~h}$; (9) $31 \mathrm{~h}$; (10) $43 \mathrm{~h}$; (11) $67 \mathrm{~h}$; (12) $73 \mathrm{~h}$; for a $0.1 \mathrm{M}$ acetate buffer $\mathrm{pH} 4.5$ solution containing $4.5 \times 10^{-3} \mathrm{M}$ of MTX. Frequency $50 \mathrm{~Hz}$. The electrode was always immersed in the solution. ( $\cdots$ ) Shows the response after $73 \mathrm{~h}$ using a freshly-polished glassy carbon electrode.

we can observe the appearance of a peak at $+1.2 \mathrm{~V}$ after $1 \mathrm{~h}$, which corresponds to the oxidation of adenine bases, and that reached its maximum after $17 \mathrm{~h}$. No peak was ever observed under these experimental conditions for a potential corresponding to oxidation of guanine. However, the MTX was in solution and not dried on the electrode surface.

\subsection{DNA-biosensor}

The DNA-biosensor was prepared as described in the experimental section. During the conditioning procedure the dsDNA film interacted with ssDNA in bulk solution, structural modification of the dsDNA immobilized on the glassy carbon surface taking place by interchain crosslinking with ssDNA in the solution.

These interesting observations can be explained through the formation of portions of triple helix DNA on the electrode surface which result from the interaction of ssDNA in the bulk solution with dsDNA on the electrode surface. Side-chain and main-chain atoms may interact with a particular DNA base-pair of another chain or with more than one base-pair supporting each other in interwoven hydrogen-bonding networks. These stabilize the contacts between the bases, forming a triple helix on the DNA adsorbed to the electrode surface (Shin and Koo, 1996; Potaman and Sinden, 1995; and Soyfer and Potaman, 1995). Hoogsteen (1959) explained the hydrogen bonds in the triple base pairing by considering the 
third strand positioned in the major groove of a WatsonCrick base pairing. Triple-stranded DNA can be generated intermolecularly or intra-molecularly; it is called $\mathrm{H}$ DNA in order to indicate the high $\mathrm{H}^{+}$concentration of the media where this triplex exists and can only be formed if one strand of the original B-helix is all purines bases, guanine and adenine, and the corresponding region of the other strand is all pyrimidines bases, thymine and cytosine.

The electrochemical characteristics of these DNAbiosensors have been evaluated (Oliveira Brett et al., 1998) and the triple-stranded DNA monitored electrochemically by hydroxylamine, a specific chemical probe for triple-stranded DNA (Johnston, 1992), formed during the electrochemical reduction of nitroimidazoles (Oliveira Brett et al., 1997). Differential pulse voltammograms of the DNA-biosensor in a buffer solution and in a solution containing ssDNA are shown in Fig. 4, and in the latter solution the peaks of guanine and adenine are clearly identified.

\subsubsection{DNA-biosensor in a solution containing sSDNA and MTX}

Since the electrochemistry of the DNA-biosensor in a ssDNA solution (Fig. 4), has been applied to study the interaction with DNA of carboplatin (Oliveira Brett et al., 1996) it was decided to use the same approach with MTX.

Differential pulse (DP) voltammograms obtained when successive $100 \mu \mathrm{l}$ aliquots of MTX of $4.5 \times$ $10^{-3} \mathrm{M}$ were added to solutions containing $60 \mu \mathrm{g} \mathrm{ml}^{-1}$ ssDNA (Fig. 5) showed that the peaks corresponding to the three peaks of MTX increased with concentration, and that the peaks currents corresponding to the oxidation of guanine and adenine from ssDNA in solution decreased. This can be interpreted by fewer base molecules being available for oxidation because of their binding with MTX (Fig. 6). Fig. 6 shows a slightly faster decrease in the peak of guanine for low concentrations but for high concentrations of MTX both peaks diminished in a similar way.

Square wave (SW) voltammograms obtained in another experiment but for the same concentrations of

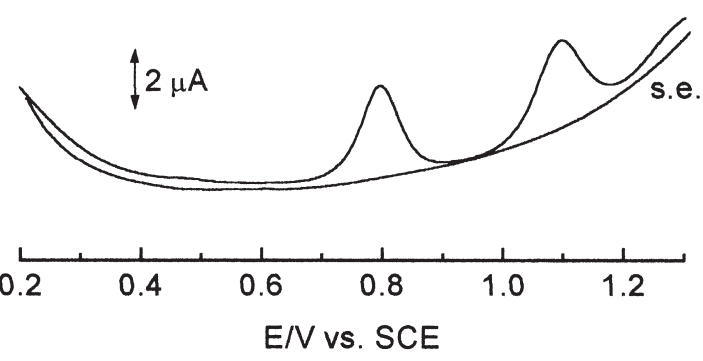

Fig. 4. Differential pulse voltammograms of a DNA-biosensor in $60 \mu \mathrm{g} \mathrm{ml}^{-1}$ ssDNA. Pulse amplitude $50 \mathrm{mV}$, pulse width $70 \mathrm{~ms}$, scan rate $5 \mathrm{mV} \mathrm{s}^{-1}$ Supporting electrolyte (s.e.) $0.1 \mathrm{M}$ acetate buffer $\mathrm{pH} 4.5$.

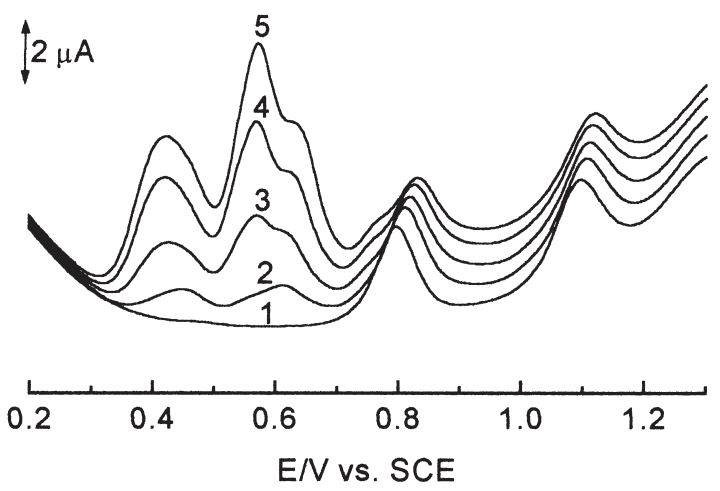

Fig. 5. Differential pulse voltammograms of a DNA-biosensor in $0.1 \mathrm{M}$ acetate buffer $\mathrm{pH} 4.5$ with $60 \mu \mathrm{g} \mathrm{ml}^{-1}$ ssDNA: (1) 0 ; (2) $45 \mu \mathrm{M}$; (3) $88 \mu \mathrm{M}$; (4) $131 \mu \mathrm{M}$; (5) $173 \mu \mathrm{M}$ of MTX. Pulse amplitude $50 \mathrm{mV}$, pulse width $70 \mathrm{~ms}$, scan rate $5 \mathrm{mV} \mathrm{s}^{-1}$.

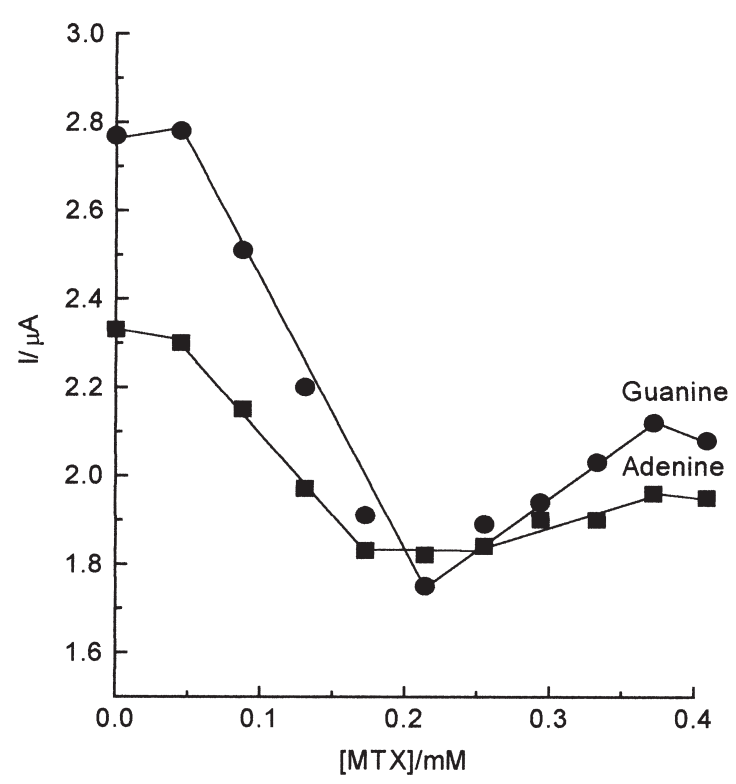

Fig. 6. Variation of the guanine and adenine peak currents in Fig. 5 with concentration of MTX.

ssDNA and MTX (Fig. 7) showed a large increase in the size of the peaks corresponding to the bases when MTX was first added followed by a great diminution of the peaks corresponding to the oxidation of guanine and adenine; these eventually disappeared after all ssDNA in solution had interacted with the MTX being added. Only two peaks corresponding to the MTX oxidation occurred at the same potential as before [Fig. 1(c)] when using a bare glassy carbon electrode.

The fact that three peaks for MTX oxidation are seen using DP voltammetry and two using SW voltammetry can be explained by considering scan rates, DP used $5 \mathrm{mV} \mathrm{s}^{-1}$ whereas in SW $100 \mathrm{mV} \mathrm{s}^{-1}$ effective scan rate was used.

The results using the DNA-biosensor show that the reaction between DNA and MTX has no preferential 


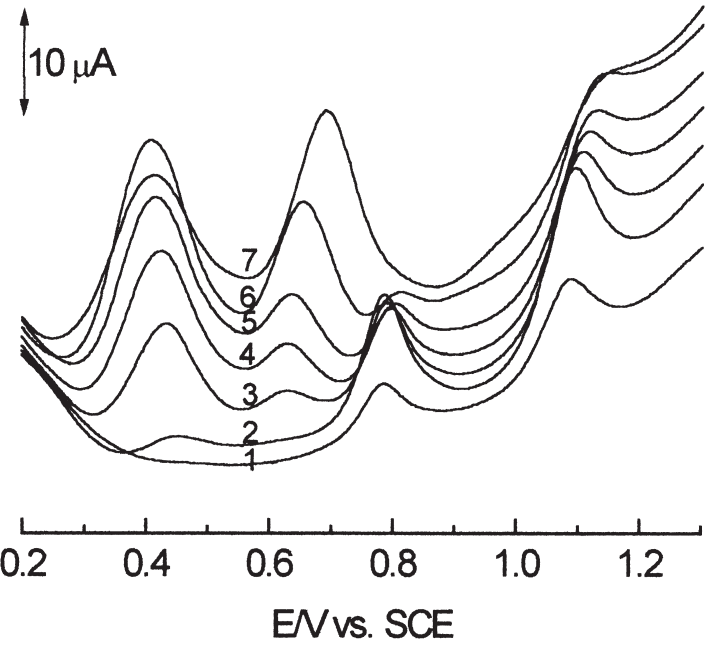

Fig. 7. Square wave voltammograms of a DNA-biosensor in $0.1 \mathrm{M}$ acetate buffer $\mathrm{pH} 4.5$ with $60 \mu \mathrm{g} \mathrm{ml}^{-1}$ ssDNA: (1) 0 ; (2) $45 \mu \mathrm{M}$; (3) $88 \mu \mathrm{M}$; (4) $131 \mu \mathrm{M}$; (5) $173 \mu \mathrm{M}$; (6) $214 \mu \mathrm{M}$; (7) $333 \mu \mathrm{M}$ of MTX. Frequency $50 \mathrm{~Hz}$.

interaction with either of the bases but that MTX has a preferential interaction with ssDNA in solution.

\subsubsection{DNA-biosensor in MTX solution}

The DNA-biosensor was used to evaluate the interaction of DNA with MTX as a function of time. Square wave (SW) voltammograms obtained when a DNAbiosensor was used in a solution containing $4.5 \times 10^{-5} \mathrm{M}$ of MTX (Fig. 8) showed besides the two peaks for the MTX, the currents of the peaks corresponding to guanine and adenine, the peak for adenine initially being bigger. After a period of $4 \mathrm{~h}$ the adenine peak decreased drastically and practically disappeared, whereas the guanine peak only decreased a little. The currents for the peaks corresponding to the oxidation of MTX became bigger due to the increase of concentration near the electrode surface of MTX that intercalated with DNA. The MTX peaks stopped increasing after $19 \mathrm{~h}$. This is in agreement with the preferential interaction of MTX with ssDNA and, as there is no ssDNA in solution, it can only be from the third strand on the DNA-biosensor.

\section{Conclusion}

This work has shown experimental evidence of interaction of MTX with DNA and may contribute to the understanding of the mechanism of action of this drug with DNA. However, with the present state of the art concerning electrochemical DNA-biosensors, although it is possible to detect the interaction between mitoxantrone and guanine and adenine bases and the results obtained using the DNA-biosensor were very reproducible, no preferential mechanism can be proposed. In fact, we can observe DNA damage occurring with time which

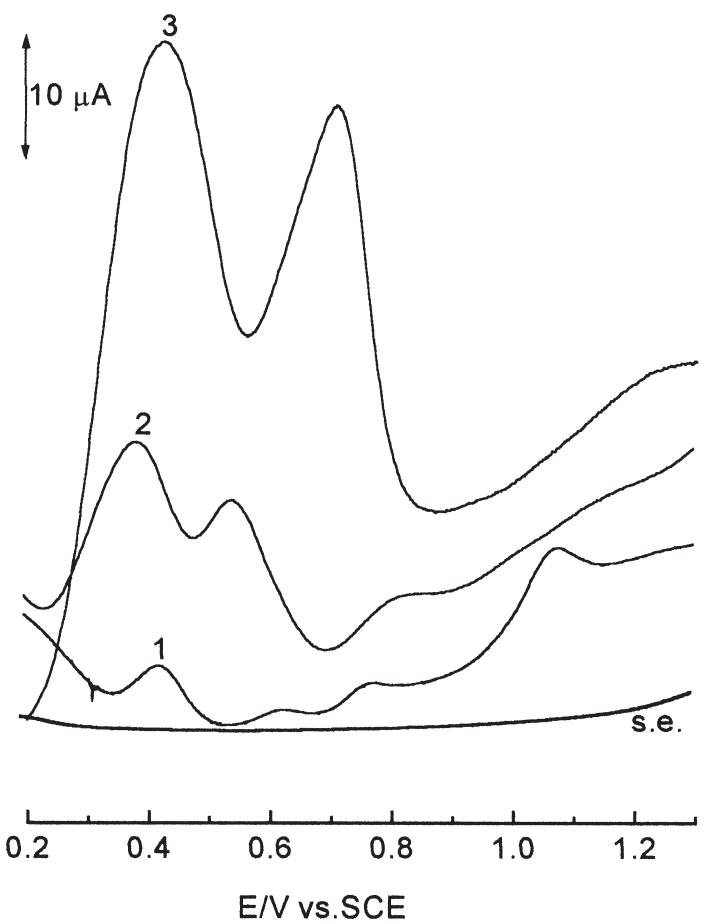

Fig. 8. Square wave voltammograms of a DNA-biosensor in solution containing $4.5 \times 10^{-3} \mathrm{M}$ of MTX. Variation with time: (1) $0 \mathrm{~h}$; (2) $4 \mathrm{~h}$; (3) $96 \mathrm{~h}$. Frequency $50 \mathrm{~Hz}$. The electrode was kept in the solution between experiments. Supporting electrolyte (s.e.) $0.1 \mathrm{M}$ acetate buffer $\mathrm{pH}$ 4.5. Frequency $50 \mathrm{~Hz}$.

suggests that MTX intercalates with DNA and slowly interacts with it causing some breaking of the hydrogen bonds. It is interesting to note that the DNA-biosensor experiments suggest preferential interaction of MTX with single-strand DNA, in agreement with previous evidence that mitoxantrone is a topoisomerase II poison.

\section{References}

Bowden, G.T., Roberts, R., Alberts, D.S., Peng, Y.M., Garcia, D., 1985. Comparative molecular pharmacology in leukemic L1210 cells of the anthracene anticancer drugs mitoxantrone and bisantrene. Cancer Research 45, 4915-4920.

Brett, C.M.A., Oliveira Brett, A.M., Serrano, S.H.P., 1994. On the adsorption and electrochemical oxidation of DNA at glassy carbon electrodes. Journal of Electroanalytical Chemistry 366, 225-231.

Capranico, G., Zunino, F., 1992. DNA topoisomerase-trapping antitumour drugs. United European Journal of Cancer 22, 1024-1030.

Dunn, C.J., Goa, K.L., 1996. Mitoxantrone: a review of its pharmacological properties and use in acute nonlymphoblastic leukaemia. Drugs and Aging 9 (2), 122-147.

Fox, M.E., Smith, P.J., 1990. Long-term inhibition of DNA synthesis and the persistence of trapped topoisomerase II complexes in determining the toxicity of the DNA intercalators mAMSA and mitoxantrone. Cancer Research 50, 5813-5818.

Foye, W.O., Vajragupta, O.P.A., Sengupta, S.K., 1982. DNA-binding specificity and RNA polymerase inhibitory activity of bis(aminoalkyl) anthraquinones and bis(methylthio) vinylquinolinium iodides. Journal of Pharmaceutical Science 71 (2), 253-257.

Hoogsteen, K., 1959. The structure of crystals containing a hydrogen- 
bonded complex of 1-methylthymine and 9-methyladenine. Acta Crystallographia 12, 822-823.

Kapuscinski, J., Darzynkiewicz, Z., 1985. Interactions of antitumor agents ametantrone and mitoxantrone (Novantrone) with doublestranded DNA. Biochemistry and Pharmacology 34 (24), 42034213.

Kapuscinski, J., Darzynkiewicz, Z., 1986. Relationship between the pharmacological activity of antitumor drugs ametantrone and mitoxantrone (Novantrone) and their ability to condense nucleic acids. Proceedings of the National Academy of Science USA. Biochemistry 83, 6302-6306.

Kapuscinski, J., Darzynkiewicz, Z., Traganos, F., Melamed, M.R., 1981. Interactions of a new antitumor agents, 1,4-dihydroxy-5,8bis-[[2-[(2-hydroxyethyl)amino]-ethyl] amino]-9,10-anthracenedione, with nucleic acids. Biochemistry and Pharmacology 30, 231-240.

Johnston, B.H., 1992. Hydroxylamine and methoxylamine as probes of DNA structure. In: Lilley, D.M.J., Dahlberg, J.E. (Eds.), Methods in Enzymology, Part B, ch. 10. Academic Press, San Diego, pp. 180-194.

Lown, J.W., Hanstock, C.C., Brabley, R.D., Scraba, D.G., 1984. Interactions of the antitumor agents mitoxantrone and bisantrene with deoxyribonucleic acids studied by electron microscopy. Molecular Pharmacology 25, 178-184.

Lown, J.W., Morgan, A.R., Yen, S.-F., Wang, Y.-H., Wilson, W.D., 1985. Characteristics of the binding of the anticancer agents mitoxantrone and ametantrone and related structures to deoxyribonucleic acids. Biochemistry 24, 4028-4035.

Murdock, K.C., Child, R.G., Fabio, P.F., Angier, R.B., Wallace, R.E., Durr, F.E., Citarella, R.V., 1979. Antitumor agents. 1. 1,4bis[(aminoalkyl)amino]-9,10-anthracenediones. Journal of Medical Chemistry 22, 1024-1030.

Oliveira Brett, A.M., Serrano, S.H.P., Macedo, T.A., Raimundo, D., Marques, M.H., La-Scalea, M.A., 1996. Electrochemical determi- nation of carboplatin in serum using a DNA-modified glassy carbon electrode. Electroanalysis 8, 992-995.

Oliveira Brett, A.M., Serrano, S.H.P., 1997. Development of DNAbased biosensors for carcinogens. In: Nikolelis, D., Frangopol (Eds.), Current Topics in Biophysics, Biosensors, vol. 6, ch. 10. Iasi University Press, Romania.

Oliveira Brett, A.M., Matysik, F.-M., 1997. Voltammetric and sonovoltammetric studies on the oxidation of thymine and cytosine at a glassy carbon electrode. Journal of Electroanalytical Chemistry 429, 95-99.

Oliveira Brett, A.M., Serrano, S.H.P., Gutz, I., La-Scalea, M.A., Cruz, M.L., 1997. Volammetric behavior of nitroimidazoles at a DNAbiosensor. Electroanalysis 9, 1132-1137.

Oliveira Brett, A.M., Serrano, S.H.P., Piedade, J.A.P., 1998. In: Compton, R.G. (Ed.), Electrochemistry of DNA. Comprehensive Chemical Kinetics, Applications of Kinetic Modelling (in press).

Potaman, V.N., Sinden, R.R., 1995. Stabilization of triple-helical nucleic acids by basic oligopeptides. Biochemistry 34, 1488514892.

Riggs, C.E., 1992. In: Perry, M.C. (Ed.), The Chemotheraphy Source Book. Williams and Wilkins, Maryland, USA, pp. 318-358.

Shin, C., Koo, H.-S., 1996. Helical periodicity of GA-alternating triplestranded DNA. Biochemistry 35, 968-972.

Smith, I.E., 1983. Mitoxantrone (Novantrone): a review of experimental and early clinical studies. Cancer Treatment Reviews 10, $103-115$.

Soyfer, V.N., Potaman, V.N., 1995. Triple-helical Nucleic Acids. Springer, New York.

Wang, J.C., 1991. DNA topoisomerases: why so many? Journal of Biological Chemistry 266, 6659-6662.

Zee-Cheng, R.K.-Y., Cheng, C.C., 1978. Antineoplastic agents. Structure-activity relationship study of Bis/substituted aminoalkylamino/anthraquinones. Journal of Medical Chemistry 21, 291-294. 